\title{
DEVELOPING MATERIALS FOR BUSINESS CROSS CULTURE THROUGH CHALLENGING ACTIVITIES
}

\author{
Singgih Widodo Limantoro \\ Business English Study Program, Politeknik Ubaya, Surabaya.
}

\begin{abstract}
Learning materials is one of the most important factors for successful learning. Developing materials through challenging activities that students need would encourage them to be more active and joyful in class. These materials are expected to minimize one of the big learning problems that students face, that is, learning boredom. Tomlinson and Masubara (2004: 2) also states that students only learn what they really need or want to learn. Another survey result (Limantoro, 2009) also mentioned factors that made students enjoy learning would be learning materials ( $57 \%$ of the respondents), learning atmosphere (53\%), delivery method (50\%) and others. The writer would develop the materials for Business Cross Culture subject to enrich the student knowledge, skills, and manners for business purposes or socialization nowadays by using classroom action research. The classroom action research cycle will start from plan, action, observation, and reflection. The next cycle is revised plan, action, observation, reflection, and then other continuous cycles. For that purpose, a survey is needed for developing materiats based on the student needs. These data would be collected from the active students who learn it and some users, such as businessmen and tourists. Further, the student reflection and feedbacks are needed for continuous improvements of these materials. The materials developed are analyzed into three kinds of categories such as must know, should know, nice to know. These categories would help the writer make priorities and design the whole materials. Moreover, he has to design the challenging activities for the materials needed by the students. Through activities in class, the writer hopes the students enjoy having theit challenging leaming experiences on a lot of cutture in class. The materiats developed are implemented into classroom activities, such as games, role-plays, case-studies, project and presentation, table manners, and discussion. These games are usually used for reinforcement of the materials. In the role-plays, the students in pairs usually simulate the right action, for instance, how to meet and greet a foreign businessman or friend and exchange their business cards. Further, by using real or authentic case studies, the students learn to solve many problems relating to Culture. Each student is also assigned to conduct a project on particular culture and prèsent the result of their projects using power points. In the digitization era, these multimedia slides are possible and enhance their presentation so that their presentation would be fruitful. The students also have to practice eating certain meals in different styles correctly. The students would not only learn the skills (eating etiquette) but also discuss the reasons or why they do that. The results of the activities would also be reflected and revised. The materials developed are analyzed and shown in the rubric of the learning materials for Business Cross Culture.
\end{abstract}




\section{INTRODUCTION}

Learning materials is also a key factor for the success of learning. It is one of the very crucial elements to conduct learning and teaching activities. The challenging learning materials would encourage the students to be more active and joyful. To develop learning materials for Business Cross Culture (BCC), one has to consider the purpose, some important principles, and the steps of developing materials for successful learning and the key elements of the instructional design process. The purpose of developing materials is to make the ideal learning materials. Richards in Sadtono (2000) states that the ideal learning materials are always in relation to the teacher, the students, and the task/ activity. First, the BCC materials help the teachers provide the adequate knowledge, skills, and manners/ attitude on the intercultural communication. The BCC materials help the teachers save time in the teaching preparation and achieve the effective learning. Second, the learning materials should fit with the students' needs, interest, language level, and challenging contents. Third, the learning materials also help students get adequate tasks which are goaloriented, graded, varied, clearly instructed, and challenging. Tomlinson and Masubara (2004: 2) also states that students only learn what they really need or want to learn. Therefore, the needs, wants, and desires in learning are also one of the important factors that teachers and the learning materials developers have to consider. Another survey resuit (Limantoro, 2009) also mentioned factors that made students enjoy learning would be learning materials $(57 \%$ of the respondents) and others. Based on the survey, it is important to provide the useful, practical, and challenging learning materials to anticipate the learning problems, such as boredom, un-motivation, and reluctance.

\section{Principles of developing materials}

The British Council in Sadtono's lecture also mentioned some important principles of developing materials that the learning materials should stimulate and develop high student motivation through their interest and needs and through the techniques applied. The learning materials should also integrate the language skills for real communication meaning the learning materials should relate to the real workplace context to encounter with 'authentic' English so that they become meaningful, practical, flexible, and usable. Further, teachers should develop learning materials as attractively as possible. The materials are arranged and presented attractively. Therefore, teachers have to use the appropriate delivery methods and challenging activities/ tasks in order to make the learning materials attractive. In addition, teachers have to develop learning materials that are worth learning. The contents of the learning materials are current information/ knowledge/ skills for their future. Ii is expected that the learning materials are desinged to foster learning. Some learning materials are also desinged to encourage critical thinking and improve life skills. Teachers who want to develop materials for learning English for Specific Purpose have to know the principles of developing materials so that the materials will be relevant to the needs or desires of the students. The principles of develping materials for learning joyfully could be taken from the following results of the students' and teachers' practice reflection (Tomlinson \& Masubara, 2004: 2) as follows:

- Students only learn what they really need or want to learn.

- Language learners only succeed of learning in a positive, relaxed, and enjoyable experience. 
- Teachers teach most successfully if they can gain some enjoyment themselves from the materials they are using.

- Materials should engage the emotions of the students because their emotions, such as joy, excitement, laughter, sorrow, and anger can also promote learning

\section{Learning materials for Business Cross Culture}

Business Cross Culture is a subject that studies essential elements of culture of the world used for socialization and business purposes. The contents of learning Business Cross Culture also start from learning languages used for socialization and business purposes. As people know that a language is the core part of culture. As a matter of fact, there are about 6,000 living languages in the world today including about 726 languages in Indonesia (Lewis, 2009). And English as the third most users in the world is used as an international language. As an international language, English users generally use English with certain cultural influence, for example Indonesians use American/ British English with Indonesian or local language accent, but when they have to communicate with Singaporeans, they have to understand Singaporean English, when they have to communicate with Filipinos, they have to understand English with Tagalog accent, and so on. Another fact, many people communicate with others from different places by using facebook or emails and other virtual ways, they may also learn some other cultural experiences. Actually people nowadays live in a global village/ world and have intercultural experience in their lives. Therefore learning English by using cross cuitural// intercuttural materials will enhance/ enrich for those learning English for socialization business purposes in this global environment. Therefore, the intercultural materials (as knowledge or skill) are useful to fullfill the needs of students for their specific purpose, for example for socialization/ networking or business negotiation, they need the intercultural materials as knowledge and skill, such as greetings with their body language, business cards exchange, table manners, and other intercultural materials. These examples could be used and developed as topics of intercultural materials for learning English for Specific Purpose (ESP),such as Cross Culture Understanding, Business Cross Culture, and so on. Examples of developing intercultural matcrials by using these topics are as follows:

- Greetings, such as 'hello' or 'good morning' in different languages and cultures. Each language and culture may have different forms of greetings. Greetings could be classified into two kinds - formal and informal. People use formal greetings,such as 'good morning' or 'good evening' to greet guests or clients in the workplace, but they use the informal greetings, such as 'hi/ hello' to greet friends/ colleagues. while greetings each other, people also have their body languages, such as shake hands, hug, kiss, bow, or salute by placing both hands together palms in front of the chest with the fingers pointing upward and others. Besides learning different greetings and their body languages, they could also learn some important daily speaking materials, such as 'thank you', 'good bye', and so on. Among the students, they could also investigate the differences and similarities of the greetings and their body languages. These could become interactive intercultural materials to enrich/ enhance language learning.

- Exchanging business-cards could also become one of the intercultural materials which usually follows greetings. Each culture has their own ways of exchanging their business cards, for example, in 
Japan, the giver should present the card with both hands and the words of the card facing to the recipient and also bow slightly.

- Table manners as eating etiquette could become useful intercultural materials for sozialization across cultures. There are a lot of table manners that could be used as the materials, such as American table manners, British table manners, Japanese table manners, Chinese table manners, Indonesian table manners, Javanese table manners, and so on.

- Food, drink/ beverage, songs, dances, costumes, tradition, and others from different regions/ countries could also become intercultural materials for learning English.

\section{Challenging Activities}

Challenging activities can be made from the learning materials and methods that are effective and joyful. The learning materials which are challenging and achieve the learning goal/ objective can be effective. The challenging learning materials and their most appropriate methods create challenging activities which may be effective and joyful. The learning materials and the learning methods should be appropriate in order to facilitate the achievement of the purposes and outcomes of the activities. The challenging materials are any learning materials that make the students learn actively and passionately for the reason that the level of difficulty of the materials are appropriate and a bit more difficult to the students' competence. The other ways to create challenging materials are providing new, current, interesting, useful/ significant learning materials relating to the instructional objectives. To have challenging materials on acquiring certain skills, teachers may use practical learning materials relating to their delivery methods, such as role-playing, simulation, and demonstrating to apply the concept of learning by doing. The learning materials can be challenging if the teachers use the most appropriate methods/ activities/ tasks and consider the appropriateness to the student ability/ competence level. If the materials tend to be dull, teachers could use warm-up / ice-breaking activities to energize their spirit to learn. The other audio-visuals, such short films from You-tube may refresh the student boredom, challenge them to think in a relaxed way, and sometimes inspire them as well. Teachers can also search for a plenty of learning sources from the internet. Teachers who prepare well and try hard for successful learning become more and more creative in providing learning activities which are really challenging. In this paper, the writer means that challenging activities could facilitate effective and joyful learning.

\section{Classroom Action Research for Developing Learning Materials}

This research used classroom action one to develop learning materials. The action research used some cycles (Kemmis, 1990) cycle I (plan $\rightarrow$ action $\rightarrow$ observation $\rightarrow$ -reflection), cycle 2 (revised plan $\rightarrow$ action $\rightarrow$ observation $\rightarrow$ reflection), and continuous cycles. In this research, there were 4 steps to develop materials for BCC. They were planning, doing, observing, and reflecting to develop learning materials. First, the writer was planning the materials rubric by collecting data from the respondents (students and users) by using questionnaires and making some interviews a a means of triangulation. Then, the data were analyzed and used as the learning materials by choosing their appropriate activities. Second, the writer was implementing the learning materials in class through challenging activities, such as games. Third, the students divided into 2 roles: the doers/players and the observers. The observation process used the fish- bowling technique that there would be two kinds of 
observers: the observers of the players and the outer observers of the observers. Fourth, the players reflected their activities they did and the observers also reflected what they observed, and the outer observers also commented on the observers and the whole process. All the students as respondents gave reflections/ feedbacks by filling out the questionnaires that were triangulated by making some interviews/phone-calls to some students that played games/did the presentation, and used certain table manners to give reflection/feedbacks/comments on what they did relating to the significance/ importance of the learning materials used. Some students that became observers had to give reflection/comments/feedbacks on what the 'players'/students did. And the other students that became outer observers had to give reflection/comments/feedbacks on the observers' reflection/feedbacks and the whole process. The researcher/writer made the revised learning materials based on all the feedbacks/ inputs given by all the respondents/ students. And the writer used the revised plan as the developed materials to make a learning material rubric.

\section{Steps to develop learning materials}

Learning materials could be the key successful learning when they are relevant, attractive, and useful. In order to be successful learning, the material developers have to develop the learning materials by using academic procedures/ steps. In this paper, the writer used somc steps to develop learning materials as follows:

- Mapping needs/ problems

- Learning objectives

- Selection of the learning topics

- Feedbacks from students and users

- Learning material rubric

- Selection of the learning materials

- Revision/ updating learning materials continuously
Here, the writer started to develop the learning materials by mapping the needs of the students and users ( of the applied knowledge or skills) and then setting the learning objectives. Learning should be related to the real-life problems/ needs. The needs mapped are necessary to select useful materials that inspire and motivate students to learn. The next step was to cluster the learning objectives into certain learning topics And then the students and users give their opinions/ feedbacks based on the learning practice by using the learning materials and significance of their learning experience. The results of the learning materials chosen are presented in learning materials rubric. Teachers may select their learning materials according to their instructional objectives. The learning materials should be relevant, attractive, and useful.Then teachers have to revise and update their learning materials continously to make learning more fruitful.

\section{Analyzing data}

Before analyzing the data, the writer collected some data by conducting a survey for developing learning materials for Business Cross Culture. The techniques used for collecting data were questionnaires and some interviews as a means of triangulation. And the respondents of the questionnaires were all the students of Business English study program of Politeknik Ubaya Surabaya $(\mathrm{N}=11)$ who took Business Cross Culture in the academic year 2011/2012, the alumni of Business English study program of Politeknik Ubaya Surabaya $(\mathrm{N}=15)$ who had ever taken Business Cross Culture, and the users: the overseas travelers/ businessmen $(\mathrm{N}=15)$. There were also 2 kinds of data of learning materials obtained by brainstorming as follows: the data of learning materials/topics and the data of learning materials for Business Cross Culture on certain countries: 
The learning materials for Business Cross Culture needed and suggested by

\begin{tabular}{lllllc}
\hline No. & Learning materials & $\begin{array}{l}\text { By students } \\
(\mathrm{N}=11)\end{array}$ & $\begin{array}{l}\text { By alumni } \\
(\mathrm{N}=15)\end{array}$ & $\begin{array}{l}\text { By users } \\
(\mathrm{N}=15)\end{array}$ & $\begin{array}{l}\text { Total average } \\
\text { scores }\end{array}$ \\
\hline 1 & Handshake, bow, kiss & $9=82 \%$ & $\begin{array}{l}8=53 \% \\
12=73 \%\end{array}$ & $69 \%$ \\
2 & Greetings & $10=91 \%$ & $7=47 \%$ & $15=100 \%$ & $79 \%$ \\
3 & Saying thank you & $11=100 \%$ & $9=60 \%$ & $15=100 \%$ & $87 \%$ \\
4 & Saying good-bye & $10=91 \%$ & $7=47 \%$ & $9=60 \%$ & $66 \%$ \\
5 & Nen-verbal & $8=73 \%$ & $7=47 \%$ & $6=40 \%$ & $53 \%$ \\
6 & Table manners & $10=91 \%$ & $5=33 \%$ & $12=73 \%$ & $66 \%$ \\
7 & Culture & $11=100 \%$ & $7=47 \%$ & $6=40 \%$ & $62 \%$ \\
8 & Stereotypes & $6=55 \%$ & $3=20 \%$ & $3=20 \%$ & $32 \%$ \\
9 & Individualism\& collectivism & $8=73 \%$ & $2=13 \%$ & $0=0 \%$ & $29 \%$ \\
10 & High-context \& low-context & $7=64 \%$ & $4=27 \%$ & $3=20 \%$ & $37 \%$ \\
& culture & & & & \\
11 & Poly-chromic \& mono-chronic & $6=55 \%$ & $2=13 \%$ & $3=20 \%$ & $29 \%$ \\
12 & Being \& doing culture & $6=55 \%$ & $4=27 \%$ & $6=40 \%$ & $41 \%$ \\
13 & Masculine \& feminine culture & $5=45 \%$ & $3=20 \%$ & $6=40 \%$ & $35 \%$ \\
14 & Honorifics & $8=73 \%$ & $6=40 \%$ & $15=100 \%$ & $71 \%$ \\
15 & Exchanging business cards & $9=82 \%$ & $7=47 \%$ & $12=73 \%$ & $67 \%$ \\
16 & Cuisine (food \& drink) & $7=64 \%$ & $2=13 \%$ & $0=0 \%$ & $26 \%$ \\
17 & Songs & $3=27 \%$ & $1=7 \%$ & $3=20 \%$ & $18 \%$ \\
18 & Dances & $3=27 \%$ & $0=0 \%$ & $0=0 \%$ & $9 \%$ \\
19 & Tips for business & $10=91 \%$ & $8=53 \%$ & $12=73 \%$ & $72 \%$ \\
20 & Tips for socialization & $11=100 \%$ & $=60 \%$ & $12=73 \%$ & $78 \%$ \\
\hline & & & & & \\
& & $7=6$ & \\
\end{tabular}

Learning materials for Business Cross Culture on countries suggested by

\begin{tabular}{|c|c|c|c|c|c|}
\hline No & Countries & Students $(\mathrm{N}=11)$ & $\begin{array}{l}\text { Alumni } \\
(\mathrm{N}=15)\end{array}$ & Users $(\mathrm{N}=15)$ & $\begin{array}{l}\text { Total average } \\
\text { scores }\end{array}$ \\
\hline 1 & Indonesia & $6=55 \%$ & $8=53 \%$ & $9=60 \%$ & $56 \%$ \\
\hline 2 & Malaysia & $4=36 \%$ & $5=33 \%$ & $6=40 \%$ & $36 \%$ \\
\hline 3 & Singapore & $5=45 \%$ & $8=53 \%$ & $9=60 \%$ & $53 \%$ \\
\hline 4 & Thailand & $10=91 \%$ & $11=73 \%$ & $12=80 \%$ & $81 \%$ \\
\hline 5 & China & $11=100 \%$ & $15=100 \%$ & $15=100 \%$ & $100 \%$ \\
\hline 6 & India & $7=64 \%$ & $9=60 \%$ & $8=53 \%$ & $59 \%$ \\
\hline 7 & South Korea & $11=100 \%$ & $14=93 \%$ & $13=87 \%$ & $93 \%$ \\
\hline 8 & North Korea & $7=64 \%$ & $6=40 \%$ & $6=40 \%$ & $48 \%$ \\
\hline 9 & Japan & $11=100 \%$ & $15=100 \%$ & $14=93 \%$ & $98 \%$ \\
\hline 10 & Timor Leste & $2=18 \%$ & $4=27 \%$ & $3=20 \%$ & $22 \%$ \\
\hline 11 & Australia & $9=82 \%$ & $12=80 \%$ & $11=73 \%$ & $78 \%$ \\
\hline 12 & New Zealand & $8=73 \%$ & $10=67 \%$ & $9=60 \%$ & $67 \%$ \\
\hline 13 & USA & $10=91 \%$ & $15=1009 \%$ & $15=100 \%$ & $97 \%$ \\
\hline 14 & Canada & $9=82 \%$ & $13=87 \%$ & $12=80 \%$ & $83 \%$ \\
\hline 15 & Brazil & $8=73 \%$ & $6=40 \%$ & $8=53 \%$ & $55 \%$ \\
\hline 16 & UK & $11=100 \%$ & $14=93 \%$ & $11=73 \%$ & $89 \%$ \\
\hline
\end{tabular}




\begin{tabular}{llllll}
\hline 17 & Netherland & $11=100 \%$ & $12=80 \%$ & $10=67 \%$ & $82 \%$ \\
18 & German & $11=100 \%$ & $14=93 \%$ & $13=87 \%$ & $93 \%$ \\
19 & France & $11=100 \%$ & $13=87 \%$ & $12=80 \%$ & $89 \%$ \\
\hline
\end{tabular}

The results of pre-test and post-test of students $(\mathrm{N}=11)$ who took Business Cross Culture in the academic year 2011/ 2012

\begin{tabular}{|c|c|c|c|}
\hline No & Pre-test & Post-test & The difference \\
\hline \multirow[t]{2}{*}{ Fest items } & Correct answer & Correct answer & \\
\hline & $\begin{array}{l}\text { Number of students \& } \\
\text { percentage }\end{array}$ & $\begin{array}{l}\text { Number of students \& } \\
\text { percentage }\end{array}$ & Percentage \\
\hline 1 & $7=67 \%$ & $11=100 \%$ & $33 \%$ \\
\hline 2 & $4=36 \%$ & $11=100 \%$ & $64 \%$ \\
\hline 3 & $4=36 \%$ & $11=100 \%$ & $64 \%$ \\
\hline 4 & $5=45 \%$ & $11=100 \%$ & $55 \%$ \\
\hline 5 & $7=67 \%$ & $11=100 \%$ & $33 \%$ \\
\hline 6 & $0=0 \%$ & $9=82 \%$ & $82 \%$ \\
\hline 7 & $0=0 \%$ & $8=72 \%$ & $72 \%$ \\
\hline 8 & $2=18 \%$ & $10=91 \%$ & $73 \%$ \\
\hline 9 & $8=72 \%$ & $11=100 \%$ & $28 \%$ \\
\hline 10 & $4=36 \%$ & $11=100 \%$ & $64 \%$ \\
\hline 11 & $8=72 \%$ & $11=100 \%$ & $28 \%$ \\
\hline 12 & $1=9 \%$ & $10=91 \%$ & $82 \%$ \\
\hline 13 & $5=45 \%$ & $11=100 \%$ & $55 \%$ \\
\hline 14 & $0=0 \%$ & $9=82 \%$ & $82 \%$ \\
\hline 15 & $4=36 \%$ & $11=100 \%$ & $64 \%$ \\
\hline 16 & $1=9 \%$ & $9=82 \%$ & $73 \%$ \\
\hline 17 & $0=0 \%$ & $8=72 \%$ & $72 \%$ \\
\hline 18 & $2=18 \%$ & $10=91 \%$ & $73 \%$ \\
\hline 19 & $6=55 \%$ & $11=100 \%$ & $45 \%$ \\
\hline 20 & $1=9 \%$ & $10=91 \%$ & $82 \%$ \\
\hline 21 & $1=9 \%$ & $10=91 \%$ & $82 \%$ \\
\hline 22 & $3=27 \%$ & $11=100 \%$ & $73 \%$ \\
\hline 23 & $1=9 \%$ & $10=91 \%$ & $82 \%$ \\
\hline 24 & $4=36 \%$ & $11=100 \%$ & $64 \%$ \\
\hline Total average & $30 \%$ & $93 \%$ & $63 \%$ \\
\hline
\end{tabular}


Moreover, the results of pre-test and post-test of all students $(\mathrm{N}=11)$ who took Business Cross Culture in the academic year 2011/2012 above were as follows:

a. Comparing the gain of the pre-test and post-test, the score range of the pre-test and post-test was $0 \%-72 \%$ while the score range of the post-test was $72 \%-100 \%$.

b. The total average score of the pre-test was $30 \%$. The total average score of the post test was $93 \%$. So the gain/difference of both tests was $63 \%$.

c. The gain/difference of both tests was the effectiveness/success of the learning process. And the success /effectiveness of the learning was contributed by some important factors, such as learning materials, methods, learning activities/tasks, and others.

Beside the quantitative data above, the writer also obtained the qualitative data by interviewing the respondents after they had done some challenging activities, such as games, simulation, and role-playing. The respondents were the students who took Business Cross Culture from Business English study program of Politeknik Ubaya Surabaya in the academic year 2011/2012. In the game activity, the players were divided into groups of three, and there was a student observer in each group. There was also an outer observer that observed the observers of the groups. The writer asked some reflective questions, such as what do you think about the activity? What do you feel about the activity?, and Do you enjoy playing/having the activity? and Why? So the reflective feedbacks from the players of the game, the observers of the game in this fishbowling observation techniques were used after the learning activities. In the game activity, the writer/lecturer used a ladder and snake board with some pawns and a dice for each group of three. The contents of the game were related to the knowledge/skills for learning Business Cross Culture. This game was provided as reviews or practice activities to reinforce what the students had learnt. Each player used a dice to determine the steps of their pawns. This game was originally adopted from the ladder snake game but the player had to do something, such as saying thank you in a certain language, to exchange business cards with a Japanese businessman, and others. The observer had the key answers. So he/she knew whether the players' responses were correct or not. And the observer would figure out the correct answer with score 1 and the wrong answer with score 0 . If one player reached the finish line, the game was over, and the highest score was the winner. And the interview session took place after the activity. The writer asked each player and observer some reflective questions, and the result of the interviews were as follows:

a. When the writer asked each player about how the game was, the players (respondents) answered that the game was very interesting, fun, challenging them to get the correct information/action through it.

b. When the writer asked each player whether the game was effective to learn Business Cross Culture, they answered that they were very helpful to answer the questions of the game or to do the action of the game.

c. When the writer asked each player how they felt about instruction of the game, they said that they felt very happy and challenged to be the winner of the game.

d. When the writer asked each player some suggestions on this activity, they said they needed longer time to play the game or to play it again.

e. When the writer asked each observer what they thought about the game, they were very good to stimulate them to understand the culture better and they 
also got the challenges to know the correct answer/action.

6. When the writer asked them what they felt about the game, they said they felt very excited and enthusiastic to play.

2. When the writer asked them some suggestions on the game/activity, they said that the time was not enough and they wanted to do the game again.

\section{FINDINGS}

Based on the data of the survey above, the sirier got some findings relating to the Sevelopment of learning materials as follows:

4. The gain/ difference between the pre-test and the post-test was high enough $(63 \%)$ due to some factors, such as the learning materials based on the needs/problems of the students and users, the challenging activities (the game) as a way to reinforce the knowledge/skill given.

b. In the pre-test, the range scores were $0 \%$ $72 \%$. In the post-test of the same test items, the range scores were $72 \%-100 \%$. The lowest score of the test item which was $0 \%$ in the pre-test was also the lowest score of the same test item which became $72 \%$ in the post-test.

c. The gain/difference between the pre-test and the post-test proved that the factors, such as the learning materials and the challenging activities/methods might foster the effective/successful learning.

d. The rubric of BCC learning materials has been categorized into three: must know $(=$ $>70 \%$ as very important materials), should know ( $<70 \%$ and $>40 \%$ as important ones), and nice to know ( $=<40 \%$ as less important ones)

The result of developing learning materials - the rubric of Business Cross Culture

\begin{tabular}{|c|c|c|c|c|c|}
\hline \multirow[t]{2}{*}{ Nas } & \multirow[t]{2}{*}{ Learning materials } & \multirow{2}{*}{$\begin{array}{l}\text { Total average } \\
\text { score }\end{array}$} & \multicolumn{3}{|c|}{ Categories } \\
\hline & & & Must know & Should know & Nice to know \\
\hline 8 & Saying thank you & $87 \%$ & V & & \\
\hline 2 & Greetings & $79 \%$ & V & & \\
\hline 5 & Tips for socialization & $78 \%$ & $\mathrm{~V}$ & & \\
\hline 4 & Tips for business & $72 \%$ & V & & \\
\hline 5 & Honorifics & $71 \%$ & V & & \\
\hline 6 & Handshake, bow, kiss & $69 \%$ & & V & \\
\hline ? & Exchanging business cards & $67 \%$ & & V & \\
\hline 8 & Saying good-bye & $66 \%$ & & V & \\
\hline 9 & Table manners & $66 \%$ & & V & \\
\hline$\$ 0$ & Culture & $62 \%$ & & $\mathrm{~V}$ & \\
\hline 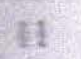 & Non-verbal & $53 \%$ & . & V & \\
\hline 12 & Being $\&$ doing culture & $41 \%$ & & V & \\
\hline 13 & $\begin{array}{l}\text { High-context \& low-context } \\
\text { culture }\end{array}$ & $37 \%$ & & & V \\
\hline 14 & $\begin{array}{l}\text { Masculine \& feminine } \\
\text { culture }\end{array}$ & $35 \%$ & & & V \\
\hline
\end{tabular}




\begin{tabular}{lllc}
\hline 15 & Stereotypes & $32 \%$ & $\mathrm{~V}$ \\
16 & $\begin{array}{l}\text { Individualism } \\
\text { collectivism }\end{array}$ & \& $29 \%$ & $\mathrm{~V}$ \\
17 & $\begin{array}{l}\text { Poly-chromic \& mono- } \\
\text { chromic }\end{array}$ & $29 \%$ & $\mathrm{~V}$ \\
18 & Cuisine (food \& drink) & $26 \%$ & $\mathrm{~V}$ \\
19 & Songs & $18 \%$ & $\mathrm{~V}$ \\
20 & Dances & $9 \%$ & $\mathrm{~V}$ \\
\hline
\end{tabular}

$f$ The rubric of $\mathrm{BCC}$ learning materials on countries has been categorized into three: must know ( $=>70 \%$ as very important materials), should know ( $<70 \%$ and $>40 \%$ as important ones), and nice to know $(=<40 \%$ as less important ones)

Rubric of learning materials for Business Cross Culture on countries

\begin{tabular}{|c|c|c|c|c|c|c|}
\hline \multirow[t]{2}{*}{ No. } & \multirow{2}{*}{$\begin{array}{l}\text { Learning } \\
\text { (countrics) }\end{array}$} & \multirow[t]{2}{*}{ materials } & \multirow{2}{*}{$\begin{array}{l}\text { Total } \\
\text { average } \\
\text { score }\end{array}$} & \multicolumn{3}{|c|}{ Categories } \\
\hline & & & & Must know & Should know & Nice to know \\
\hline 1 & China & & $100 \%$ & V & & \\
\hline 2 & Japan & & $98 \%$ & V & & \\
\hline 3 & USA & & $97 \%$ & V & & \\
\hline 4 & German & & $93 \%$ & V & & \\
\hline 5 & South Korea & & $93 \%$ & V & & \\
\hline 6 & UK & & $89 \%$ & V & & \\
\hline 7 & France & & $89 \%$ & V & & \\
\hline 8 & Canada & & $83 \%$ & V & & \\
\hline 9 & Netherland & & $82 \%$ & V & & \\
\hline 10 & Thailand & & $81 \%$ & V & & \\
\hline 11 & Australia & & $78 \%$ & V & & \\
\hline 12 & New Zealand & & $67 \%$ & & V & \\
\hline 13 & India & & $59 \%$ & & V & \\
\hline 14 & Indonesia & & $56 \%$ & & V & \\
\hline 15 & Brazil & & $55 \%$ & & V & \\
\hline 16 & Singapore & & $53 \%$ & & V & \\
\hline 17 & North Korea & . & $48 \%$ & & V & \\
\hline 18 & Malaysia & & $36 \%$ & & & V \\
\hline 19 & Timor Leste & & $22 \%$ & & & V \\
\hline
\end{tabular}




\section{CONCLUSION}

Learning materials through challenging activities will promote effective/successful larning. Developing the learning materials fire effective learning, teachers have to know the needs of the learners, the current problems of the users (those who apply the 4 tiuslcdge/ skills). The students want to learn shat they really need and the learning process sill be more interesting if they learn the knowledge/skills they really need through challenging activities/methods. In this paper, the writer used the action research cycle: planning, doing (action), observing (bbservation), and reflecting (reflection) and a survey by using questionnaires with some interviews. The writer found out that the learning materials based on the needs of students and users with challenging activities/methods were effective to foster the learning. The gain shown in the pre-test and the post-test was high enough (63\%), In their netlective interviews, the students (as the players or observers of the game activity) also found out that the activity reinforcing their knowledge and skills on Business Cross cuiture was very interesting, challenging, and belpful. It was proven by the significant gain the students got. In the pre-test, the range scores were $0 \%-72 \%$ and in the post test, the tringe scores of the same test items were $72 \%$ $100 \%$. The lowest score of the test item which was $0 \%$ in the pre-test was also the lowest score of the same test item which became $72 \%$ in the post-test.
Moreover, there were at least two important things to make students learn effectively and joyfully: the learning materials and the challenging activities. The students expected the useful learning materials with challenging activities. Furthermore, the teachers have to know the principles and steps of developing lcarning materials which are really challenging for students. The ideal learning materials are developed by considering the needs of the students including the student ability/ competence, the relevancy to their daily life, and the challenging activities. The materials developed are analyzed and shown in the rubric of the learning materials for Business Cross Culture. 


\section{REFERENCES}

Allwright, R.L. 1990 What Do We Want Teaching Materials For? In R.Rossner and R Bolitho,(Eds), Currents in Language Teaching. Oxford: Oxford University Press.

Ariew, R. 1989 Adapting Materials. The textbook as Curriculum in Sadtono, Material Development. Illinois: National Textbook

Brake, Terence, Danielle Medina Walker, Thomas Walker. 1995. Doing Business Internationally The Guide to Cross Cuiturai Success. New York : Irwin.

British Council. 1980 Project in Materials Design. Material Development Principles, in Sadtono.

Dennison, W.F. and Kirk R. 1990 Do, Review, Learn, Apply. A Simple Guide to Experiential Learning. Oxford: Blackwell.

Guy, Marilyn. 2003. The International Business Book. Lincolnwood: NTC Business Books.

Kemmis, S \& Mc Taggart R. 1990. The Action Research Reader. Victoria: Deakin Univ

Lewis, Marilyn. 2003 Giving Feedback in Language Classes. Singapore: RELC.

Lewis, M. Paul. 2009. Ethnoloque:Languages of the World. Retrieved on 5 October 2012 from the World Wide Web// www.wikipedia.org/wiki/languages of Indonesia.

Limantoro, Singgih Widodo. 2010. Developing Intercultural Materials for Learning English Joyfully. Jurnal Ilmiah social \& Humaniora vol 4 no 1 Desember 2010 page $61-69$ ISSN 02161532

Mitchell, Charless. 2008. International Business Culture, $3^{\text {rd }}$ ed. Petaluma: World Trade Press.

Morrison, Terri and Wayne A Conaway. 2006. Kiss, Bow or Shakehands. Avon : Adams Media.

Mortison, Terri and Wayne A Gonaway. 2007. Kiss, Bow or Shakehands: Asia. Avon: Adams Media.

Morrison, Terri and Wayne A Conaway. 2007. Kiss, Bow or Shakehands: Europe. Avon : Adams Media.

Morrison, Terri and Wayne A Conaway. 2007. Kiss, Bow or Shakehands: Latin America. Avon: Adams Media.

O’Neill, R. 1990 Why Use Textbooks? In R. Rossner and R. Bolitho (Eds), Currents in Language Teaching. Oxford: Oxford University Press

Tomlinson, Brian and Hitomi Masuhara. 2004. Developing Language Course Materials. Singapore: RELC. 


\section{JURNAL ILMIAH}

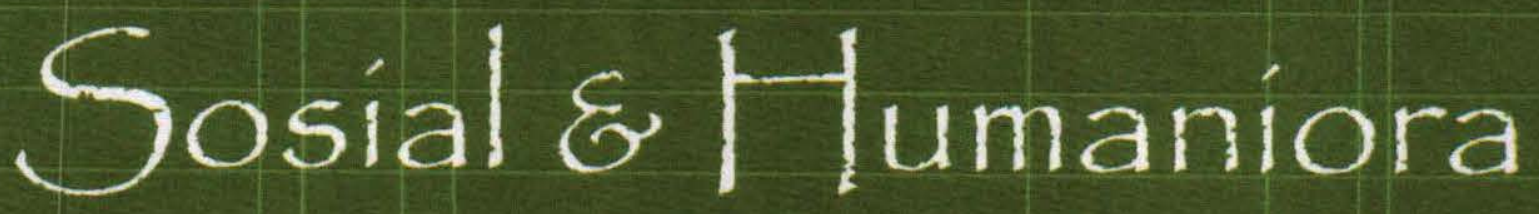

JOURNAL OF SOCIAL \& HUMANITY

Singgih Widodo Limantoro

DEVELOPING MATERIAIS FOR BUSINESS CROSS CULTURE

THROUGHCHALLENGING ACTIVITIES

Rizky Eriandani

ANALISIS PENGUNKAPAN TANGGLNG IAWAB SOSIAL

PADA PERBANKAN SYARIAH BERDASARKAN TAIWHIDIC APTROACH

Bambang Budiarto

ESTIMASI NTERVAL BLAYA HIDUP MAHASISIVA

DALAM MENEMPUH PENDIDIK AN TINGG

Ahmad Zafrullah Tayibnapis

ANALISIS KEPEMII IK AN ASING DAN STRATEGI

PENGENDALIAN DOMINASINYA DAL AM PEREK ONOMLAN INDONESIA

Sri Sarjana

PENGARUH MOTIVASIDAN EFEKTIVITAS KEPEMIMPINAN

TERHADAP PRODUKIIVITAS 


\title{
JURNAL ILMIAH \\ SOSIAL \& HUMANIORA
}

ISSN 0216-1532

Terbit dua kali setahun pada bulan Juni dan Desember. Berisi tulisan yang berasal dari hasil penelitian, kajian atau karya ilmiah di bidang Sosial dan Humaniora.

Ketua Penyunting

Ketua Lembaga Penelitian dan Pengabdian Kepada Masyarakat

\author{
Penyunting Pelaksana \\ Jatie K. Pudjibudojo \\ Sujoko Efferin \\ A. Hery Pratono \\ Hartanti
}

Staf Pelaksana

Tang Hamidy, Hadi Krisbiyanto, Sukono

Penerbit

Lembaga Penelitian dan Pengabdian Kepada Masyarakat

Universitas Surabaya

\section{Alamat Penerbit/Redaksi}

Gedung Perpustakaan LtIV, Universitas Surabaya

Jalan Raya Kalinungkut, Surabaya, 60293

Telp. (031) 2981360, 2981365

Fax. (031) 2981373

Website : http://ppm.ubaya.acid

E-mail : lppm@ubaya.acid

Jurnal Ilmiah Sains dan Teknologi pernah terbit dengan nama Unitas (pertama kali terbit tahun 1992) oleh Lembaga Penelitian Universitas Surabaya.

Isi di huar tanggung jawab Percetakan. 


\title{
JURNAL ILMIAH \\ SOSIAL \& HUMANIORA
}

ISSN 0216-1532

Volume 6 Nomor 1, Desember 2012

Halaman 168

\author{
Singgih Widodo Limantoro \\ DEVELOPING MATERIALS FOR BUSINESS CROSS CULTURE THROUGH \\ CHALLENGING ACTIVITIES \\ (hal: 1-12) \\ Rizky Eriandani \\ ANALISIS PENGUNKAPAN TANGGUNG JAWAB SOSIAL PADA PERBANKAN \\ SYARIAH BERDASARKAN TAWHIDIC APPROACH \\ (hal: 13-26) \\ Bambang Budiarto \\ ESTIMASI INTERVAL BIAYA HIDUP MAHASISWA \\ DALAM MENEMPUH PENDIDIKAN TINGGI \\ (hal: 2741)
}

Ahmad Zafrullah Tayibnapis

ANALISIS KEPEMILIKAN ASING DAN STRATEGI PENGENDALIAN

DOMINASINYA DALAM PEREKONOMIAN INDONESIA

(hal: 42-56)

Sri Sarjana

PENGARUH MOTIVASI DAN EFEKTIVITAS KEPEMIMPINAN TERHADAP

PRODUKTIVITAS

(hal: 57.68) 